\title{
Promoting Democracy Through Regional-International Instruments: The Role Of Commonwealth Africa Judiciary
}

\author{
By Kaniye S.A. Ebeku, Port Harcourt / Nicosia
}

\section{Introduction}

For several years, and until recently, nearly all African countries (particularly commonwealth African countries) were under one form of undemocratic government or the other. Some were under military dictatorships, while others were under one-party system of governments. ${ }^{1}$ In the former case, democratic elections were hardly conducted. Where elections were conducted at all (maybe at the local level), their outcomes were pre-determined. In the latter case, 'elections' were merely a ritual, as the outcomes of such exercises were also pre-determined. In those situations, oppression reigned supreme and dissent was outlawed and punishable as a crime - sometimes on death penalty. Remarkably, the Judiciary, which traditionally should be the last hope of the common-man or the oppressed, could not exercise its powers, as legislative provisions of the ruling junta usually contain privative/ouster clauses.

Nigeria is the most populous State in Africa and one of the worst cases of military dictatorships in the continent. Of the over 40 years of its independent existence from 1 October 1960 , the country was under several and successive military dictatorships for over twothirds of the years. In fact, the country returned to democratic governance only on 29 may 1999 , after about 15 unbroken years of military governance. The military rule that ended on 29 May 1999 had come into political power on 31 December 1983, by toppling a democratically elected government against the letters of the 1979 Constitution of Nigeria.

Apart from deprivation of personal liberty and all other forms of human rights abuses, Africans under dictatorial regimes suffered underdevelopment, economic deprivations and abject poverty. The wealth of the country was stolen and stashed away in foreign banks by those in political power and members of their families. The cases of Zaire and Nigeria are illustrative of this point. In Zaire, President Mobutu Sese Sekou stole a lot of money belonging to the country and banked the same in private accounts abroad. Similarly, in 
Nigeria Gen. Abacha and his family members (Gen. Babangida, his family members, friends and cronies, before them) stole a lot of State money and sent to their private foreign bank accounts. Regrettably, it has not been possible to recover all the stolen State money since the end of the iron-fisted regimes, despite all (sometimes, though, half-hearted) efforts by succeeding governments.

Interestingly, the wave of democracy began to sweep through the African continent in the 1990s, and is continuing. ${ }^{2}$ In fact, it would seem that Africans have realised the evils of dictatorship and are determined to rout it out and pursue democracy. At the regional level, Africans have made a number of pro-democracy statements, declarations and agreements through their "new" leaders. Clearly, this approach indicates that the virtues of democracy are seen as the common concern of all Africans, which should be tackled cooperatively. This article attempts to examine the role of the judiciary in the promotion and sustenance of democracy in Africa, against the background of relevant regional-international instruments.

\section{Declarations of Democratic principles in Africa}

By several recent instruments - statements of principles, declarations, and agreements African countries have committed themselves to the practice of democratic governance. For example, the New Partnerships for Africa's Development (NEPAD) - a Vision and Strategic Framework for Africa's renewal - commits the whole of Africa to respect the global standards of democracy, the core components of which include political pluralism and fair, open and democratic elections periodically organized to enable the people to choose their leaders freely. More specifically, it commits African leaders to take joint responsibility "to promote and protect democracy and human rights in their respective countries and regions, by developing clear standards of accountability, transparency and participative governance at the national and sub-national levels". 3

Secondly, in the Declaration on the Framework for an OAU Response to Unconstitutional Changes of Government, African Heads of State and Government stated their commitments to democracy. ${ }^{4}$ In the preamble of this declaration, they noted that they "have undertaken a review of the political developments on the continent and in particular the state of consoli-

2

See 'Pro-democracy Movements Sweep Africa', supra.

See NEPAD "A New African Initiative" (available online at: http://www.touchtech.biz/nepad/ files/documents/anewafricaninitiative.pdf).

Organisation of African Unity (OAU), "Declaration on the framework for an OAU Response to Unconstitutional Changes of Government" (made by the Assembly of Heads of State and Government, $36^{\text {th }}$ Ord. Sess., O.A.U. Doc. AHG/Decl. 5 (XXXVI), Lome, Togo (2000), (available online at: http://www.au2002.gov.za/docs/summit_council/lome2.htm). 
dating democracy in Africa", and expressed their "grave concern about the resurgence of coup d'etat in Africa". In their words: "We recognize that these developments are a threat to peace and security of the continent and they constitute a very disturbing trend and serious set back to the on-going process of democratisation in the continent". 5

Substantively, this declaration proclaims a continent-wide commitment to democracy and proceeds to give substance to that commitment by setting out "common values and principles for democratic governance" in African countries, including respect for the constitution and adherence to the provisions of the law and other legislative enactments adopted by Parliament; promotion of political pluralism or any other form of participatory democracy and the role of the African civil society, including enhancing and ensuring gender balance in the political process; the principle of democratic change and recognition of a role for the opposition; and the organization of free and regular elections, in conformity with existing texts. The declaration rejects any unconstitutional change in government as an anachronism and a contradiction to Africa's commitment "to promote democratic principles and conditions".

Remarkably, the Declaration on the Framework for an OAU Response to Unconstitutional Changes of Government is in accord with and reinforces section 1 (2) of Nigeria's current (1999) Constitution, which provides that "the Federal Republic of Nigeria shall not be governed, nor shall any persons or group of persons take control of the Government of Nigeria or any part thereof, except in accordance with the provisions of this Constitution".

Furthermore, the determination of African leaders (and their peoples) to promote and practise democracy can be found in the Constitutive Act of the African Union (AU). The preamble of this document expressed the determination of African leaders to "consolidate democratic institutions and culture and to ensure good governance and the rule of law". 6 Accordingly, one of the declared objectives of the new organisation (which replaces the Organisation of African Unity (OAU)) is the "promotion of democratic principles and institutions, popular participation and good governance" (article 3(g)). In unequivocal terms, the leaders agreed that "governments which shall come to power through unconstitutional means shall not be allowed to participate in the activities of the Union" (article 30).

More recently, African Heads of State and Government made a Declaration on the Principles Governing Democratic Elections in Africa, ${ }^{7}$ which reaffirms the principles of democ-

5

Ibid.

6 African Union, "Constitutive Act of the African Union", July 2000, CAB/LEG/23.15 (entered into force on 26 May 2002) (available online at: http://www.au2002.gov.za/docs/key_oau/au_act.pdf).

7 See OAU/AU, "Declarations on the Principles Governing Democratic Elections in Africa" (made by the Assembly of Heads of State and Government, $38^{\text {th }}$ Ord. Sess., O.A.U. Doc. AHG/Decl 1 
ratic governance in earlier instruments and asserts, inter alia, that "democratic elections should be conducted: (a) freely and fairly; (b) under democratic constitutions and in compliance with supportive legal instruments; (c) under a system of separation of powers that ensures in particular, the independence of the judiciary; (d) at regular intervals, as provided in national constitutions; and (e) by impartial, all-inclusive competent accountable electoral institutions staffed by well-trained personnel and equipped with adequate logistics" (Para. II (4)).

Although declarations are regarded as "soft-law" (not legally binding), and not "hard-law" (treaties or conventions, which are legally binding), it seems that the consistency of the declarations indicates a clear intention to be bound by them. Moreover, it has come to be recognised that declarations of the principal organs of an international organisation (such as the UN General Assembly or the Assembly of the OAU/AU; or the statements of State officials, such as the Head of State or a Minister) is one way to indicate State practice, as an evidence of customary international law (in this case, for the countries of the African continent). In any case, the declarations would appear to have received hard-law expression in the Constitutive Act of the African Union, as seen above. Significantly, it is specifically provided under article 23 of the Act that "any Member State that fails to comply with the decisions and policies of the Union may be subjected to... sanctions, such as the denial of transport and communications links with other Member States, and other measures of a political and economic nature to be determined by the Assembly".

The crucial question for this article is: how may the judiciary assist in the promotion and sustenance of democracy in commonwealth Africa, having regard to these and other relevant (pro-democracy) regional-international-instruments?

\section{The Judiciary and the Promotion and Sustenance of Democracy in Africa}

The African judiciary, particularly the judiciary in Commonwealth Africa, has been faced several times in the past with questions relating to the promotion or sustenance of democracy or constitutionalism. Three examples drawn from decided cases will serve to bear out this fact.

Firstly, in the Nigerian case of Lakanmi v. Attorney-General (Western State), ${ }^{8}$ the Supreme Court of Nigeria was faced with the question whether the 1963 Constitution of the country had been abrogated by the mutinous acts of a section of the country's army and whether the

(XXXVIII), Durban, South Africa (2002), available online at: http://www1.umn.edu/humanrts/ africa/ahg 171-184.html.

8

(1971) 1 U.I.L.R. (Pt. 2) 201. 
elected officers of government at the time had been permanently and legally replaced in their political offices by unelected military officers. On 15 January 1966, a section of the army attempted to forcefully seize power from a democratically elected government. Key political figures were abducted and killed, including the Prime Minister of the country. However, they failed to take over the government, and it was claimed that the remaining officers of the Federal Government (both elected and appointed officers) invited the army to form an interim government, and the invitation was accepted. A question as to the nature of the military government - its legality or legitimacy - arose in this case, on issues relating to the (legislative) powers of the government. While the Attorney-General of Western State argued that the events of 15 January 1966 amounted to a revolution - a forcible substitution of a new ruler or form of government, the opposing counsel contended that the event was not a revolutionary one and that the government formed was a constitutional interim government' - whose acts can only be justified by the doctrine of state necessity, otherwise they remain unconstitutional. After due consideration of the facts, the Supreme Court took the view that the events of January 1966 did not result in a revolution. However, it agreed that had it been a revolution, it would have effectively operated to overthrow the 1963 Constitution of Nigeria and established a new legal order in its stead. In other words, the court accepted revolution (for example, a successful coup by military officers against an elected government) as a legitimate way to change a democratic/constitutional government.

Secondly, in Uganda v. Commissioner of Prisons, ex p. Matovu, ${ }^{9}$ the Ugandan High Court (the country's highest court then) faced the question whether the Prime Minister can unilaterally remove the President and Vice-President of the country from office and take over their constitutional functions, as he declared that he had done. Further, the court had to answer the question whether the 1962 Constitution of Uganda had been legally replaced by the promulgation and adoption of another Constitution in 1966 without recourse to its amendment provisions. The court held that the successful acts of forcibly removing the President and Vice-President from office and the taking over of their functions by the Prime Minister as well as the adoption of another Constitution to replace the 1962 one amounted to a revolution, the effect of which was to establish a new legal order. Quoting approvingly from a Pakistani decision, ${ }^{10}$ the court stated that "a victorious revolution is an internationally recognised legal method of changing a constitution [and replacing the officers elected under it]". Furthermore, it held that "no jurist would maintain that even after a successful revolution, the old constitution and the laws based thereon remain in force, on the ground that they have not been nullified in a manner anticipated by the old order itself', 11

(1966) E.A. 514.

10 State v. Dosso (1958) 2 P.S.C.R. 180.

11 Uganda v. Commissioner of Prisons, ex p. Matovu (1966) E.A. 514, at 538. 
The third and most recent case is the case of Mokotso v. King Moshoeshoe, ${ }^{12}$ in which the Chief Justice of Lesotho had to decide the legality of a government formed after a coup d'etat. It all started by the nullification/invalidation by the Prime Minister of a general election won by an opposition party in 1970, and his continuation in power. In 1985, an election was held in which only the members of the ruling party were allowed to be candidates and were returned unopposed. The government was toppled by a Para-military coup d'etat in 1986. In this case, where the legality of the extra-constitutional actions arose, the judge held that "successful revolutions established new legal orders" - meaning, among others, that the democratic, free and fair election of 1970 was legally invalidated by the action of the Prime Minister. He relied on what he called "the course of history" and also on the Kelsenite theory of revolutionary legality. ${ }^{13}$ As he stated, "a court may hold a revolutionary government to be lawful, and its legislation to have been legitimised ab initio, where it is satisfied that: (a) the government is firmly established, there being no other government in opposition thereto; and (b) the government's administration is effective, in that the majority of the people are behaving, by and large, in conformity therewith".

As has been seen, these cases were decided on the theory of revolutionary legality and/or the doctrine of state necessity. The result was that the unconstitutional changes of government were given judicial seal of approval. However, the Nigerian case may be seen in one sense as a bold attempt to resist unconstitutional change of a democratic government. The crucial question at this juncture, however, is whether these cases would, or should, be decided differently today, having regard to the regional/intergovernmental instruments outlined above. The answer suggested below is in the affirmative.

It may be observed that the above cases involved 'major' events. Again, the cases, or the events giving rise to them, arose so early after the attainment of independence by the countries in question. ${ }^{14}$ Furthermore, at the time of those cases there was no specific regional or international instrument available to the courts that could have guided their decisions. Legal theories were the only available aids. Even so, unfortunately, the courts appeared to have failed in their role as guardians of their respective country's constitution and democracy, by their decisions which encouraged unconstitutional changes of government; and this probably explains why coup d'etat was a frequent and recurrent phenomenon in the continent.

13 See Kelsen, General Theory of Law and State (translated by Anders Wedberg) 1949, Cambridge, Mass.: Harvard University Press. 
In the prevailing movement to democracy in Africa, judges cannot afford to be seen to rely on abstract theories when dealing with issues relating to the sustenance of democracy. They have a role to play in implementing the principles of democracy enunciated in the various instruments mentioned above: before elections, during elections and after elections. Specifically, and consistent with the relevant instruments, judges can and should promote democracy in the course of resolving pre-election suits and election petition cases - by ensuring that the appropriate laws are complied with; that the rules of the game are followed. If a coup d'etat or other unconstitutional change of government occurs and its legality comes to question before them, they should invoke and rely on relevant regional instruments (except in cases of grave emergency - relating to the survival of the State itself, when recourse might be made to the doctrine of state necessity) in reaching their decisions.

In principle, the doctrine of state necessity can be said to be consistent with democracy or constitutionalism. In fact, the experience of the Republic of Cyprus (a member of the Commonwealth) profoundly bears this out. Following "the anomalous circumstances which arose during 1963", ${ }^{15}$ the court invoked the doctrine of state necessity, and this has helped to preserve democracy in the country for over 40 years now.

The ingenuity of the court was tested in Attorney-General of Cyprus v. Mustapha Ibrahim. ${ }^{16}$ In brief, there was communal violence in 1963 between the two main communities of the country, i.e. Greek Cypriots and Turkish Cypriots, which snowballed into the withdrawal of the Turkish-Cypriots from the various organs of government. It was such that the government of the country could no longer function in terms of the Constitution, and the survival of the State was threatened. This case was a legal challenge on the constitutionality of a law made in the prevailing circumstances to ensure the continuation of administration of justice and avoid a breakdown of law and order in the country. Although the court agreed that the law was not made in accordance with the strict letters of the Constitution, it held that in the prevailing circumstances it was saved by the doctrine of state necessity. As one author put it, the court invoked the doctrine of state necessity to empower the organs of state with "legal authority required to solve legal problems created by the Turkish Cypriots" rebellion against the State which otherwise, if not solved by the application of this doctrine, would have undermined the rule of law in Cyprus". 17 2000, New York: Yorkhill Law Publishing, 15, at 39. (1964) CLR 195. 
The judgment of Mr Justice Vassiliades in the case is illuminating. He said:

This court now, in its all-important and responsible function of transforming legal theory into living law applied to the facts of daily life for the preservation of social order is faced with the question whether the legal doctrine of necessity...should or should not be read [into] the provision of the written Constitution of the Republic of Cyprus. Our unanimous view, and unhesitating answer to this question, is in the affirmative. $^{18}$

It is remarkable that the judge recognised the function of the court as "all-important" and "responsible". His learned brother, Mr Justice Josephides, went further to set out the parameters for the invocation of the doctrine of state necessity. His words:

In the light of the principles of the law of necessity as applied in other countries ... I interpret our Constitution to include the doctrine of necessity in exceptional circumstances which is an implied exception to particular provisions of the Constitution; and this is to ensure the very existence of the State. The following pre-requisites must be satisfied before the doctrine may be applicable:

a) an imperative and inevitable necessity of exceptional ... circumstances;

b) no other remedy can apply;

c) the measure taken must be proportionate to the necessity; and

d) it must be of a temporary character limited to the duration ... of the exceptional circumstances $^{19}$ (Emphasis added).

It is possible that judges may be constrained by domestic laws, but the regional instruments can, and/or should, be held to prevail over domestic laws. As the Nigerian Supreme Court has rightly observed with regard to the Africa Charter on Human and People's Rights:

[W] here we have a treaty like the Africa Charter on Human and Peoples' Rights and similar treaties applicable to Nigeria, we must be prepared to stand on the side of civilised societies the world over in the way we consider and apply them...This will necessarily extract from the judiciary...its will and resourcefulness to play its role in the defence of liberty and justice [and democracy]... The judiciary must not be seen as assisting those who step on liberty and justice [and democracy] to effectively press them down...I subscribe to every view which supports the attitude that "we cannot afford to be immuned (sic) from the progressive movements manifesting themselves in international agreements, treaties, resolutions, protocols and other similar understandings as well as in the respectable and respected voices of our learned brethren in the performance of their adjudicating roles in other jurisdictions"... 20

Attorney-General of Cyprus v. Mustapha Ibrahim, at 214.

19

20

Attorney-General of Cyprus v. Mustapha Ibrahim, at $264-265$.

Abacha v. Fawehinmi [2000] 6 N.W.L.R. (Pt. 660) 228, at 342 - 343 (citing the words of Aguda, JCA in Attorney-General of Botswana v. Unity Dow (1988) 1 Human Rights Law Reports of Africa 27, Per Uwaifo, JSC. 
It is interesting to note that section 39(1) (b) of the Constitution of South Africa 1996 provides that "when interpreting the bill of rights, a court, tribunal, or forum must consider international law". Moreover, section 39 (1) (a) provides that when interpreting the bill of rights a court or tribunal "must promote the values that underlie an open and democratic society". Furthermore, section 233 of the Constitution generally provides that "when interpreting any legislation, every court must prefer any reasonable interpretation of the legislation that is consistent with international law over any alternative interpretation that is inconsistent with international law". This is similar to article 25 of the Basic Law of the Federal Republic of Germany, which specifically provides that "the general rules of public international law are an integral part of federal law. They shall take precedence over the laws". The same position also applies generally in the United States. ${ }^{21}$

Notably, the South African constitutional provisions may form the legal basis for South African courts to invoke relevant international instruments to the end of promoting and sustaining democracy in South Africa. For example, they will be handy when considering the legality of any legislative measure issued by a government which had come into power unconstitutionally.

It is significant to note that in interpreting section 39(1) of the Constitution the Constitutional Court of South Africa has adopted the approach that 'all sources of international law, binding and non-binding, must be considered'. 22

And in South African National Defence Union v. Minister of Defence, ${ }^{23}$ the Constitutional Court sought out and applied international law. In that case, the court considered the prohibition of membership of trade unions by members of the Permanent Force. The court relied on certain conventions and recommendations of the International Labour Organisation and held that the total ban on trade unions in the Defence Force was unreasonable and unjustifiable.

The absence of specific constitutional provisions similar to South Africa's in the Constitutions of other Commonwealth Africa countries cannot be an argument for not adopting a progressive approach as suggested by the Nigerian Supreme Court (see above). After all, judicial activism is a current and an increasing trend worldwide. 


\section{Concluding Remarks}

Notwithstanding doctrinal arguments, a democratic system of government provides the most fertile ground for development in all ramifications. In any case, it is better than and preferable to a dictatorship. By various recent regional-international instruments, African countries have expressed firm commitment to the practice and ideals of democracy. This is a major and interesting development. The political arms of government (the executive and the legislature) alone cannot achieve the targeted goal. The judiciary has a great role to play in promoting and sustaining democracy in Africa - specifically in commonwealth Africa, which is riddled with underdevelopment, poverty and corruption, occasioned by several years of being ruled under dictatorships.

All over the world, it is well recognised that the traditional role of the judiciary is the implementation of laws - both domestic and international laws. If judges fail in their duties, the laws (no matter how good on paper) may remain dead letters. At the Global Judges symposium in Johannesburg in August 2002 - held a week before the Johannesburg World Summit on Sustainable Development (WSSD) - the Executive Director of the United Nations Environment Programme (UNEP) underlined the role of the judiciary in promoting sustainable development: by the enforcement and implementation of relevant domestic laws and international instruments. He pointed out that unless the relevant laws are implemented and enforced by judges they remain little more than 'symbols, tokens, and paper tigers' ${ }^{24}$ The implication of this is that the judiciary is a crucial partner in the promotion and sustenance of sustainable development in the world. In the same way, the judiciary is surely a crucial partner in the promotion and sustenance of democracy in Africa.

The words of the pro-democracy regional-international instruments (few of which have been stated above) may remain dead letters unless the judiciary breathes life to them. The opportunity for judges to breathe life to them, and thereby promote democracy, can come at 
any time - even in cases that may be patently unrelated to the subject of democracy. If the attitude recommended here is adopted, this will help to promote and sustain democracy in Africa in general and commonwealth Africa in particular. ${ }^{25}$

25 At the international level, the African Commission on Human and Peoples' Rights and the proposed African Court of Justice (see article 18 of the Constitutive Act of the African Union), would also be of great assistance in the promotion and sustenance of democracy in Africa. In appropriate cases, it is recommended that they should follow the approach recommended for domestic courts. 